\title{
The Making of a Soviet Hero: the Case of Spartacus
}

\author{
Oleksii Rudenko | ORCID: 0000-0002-0233-9783 \\ Postgraduate Student, Centre for European Studies, Jagiellonian University \\ in Kraków, Kraków, Poland \\ Postgraduate Student, Central \& East European Studies, University of \\ Glasgow, Glasgow, UK \\ olexiy.rudenkog7@gmail.com
}

\begin{abstract}
This article examines the process of establishing the image of ancient slave rebellion leader Spartacus in the early Soviet era, with a focus on the 1920 s and 1930s. Although the image of Spartacus in Soviet historiography has been investigated by scholars, the process of acculturation and reception of his figure within toponymy, onomastics, sport, and history-writing has not been researched as a holistic approach of Soviet propaganda. This article traces how and why Spartacus's image became the primary figure of the classical antiquity in Soviet propaganda of the 1920s. The article argues that it was not Soviet historiography in the 1920s that shaped his image to be embodied in the Soviet narratives and public space. Rather, art, local toponymy, and sports created and promoted a particularly Soviet reception of Spartacus in the 1920s and 1930s which provided implications for socialist Central-Eastern European countries in the post-World War II era.
\end{abstract}

\section{Keywords}

Spartacus - sports - Soviet Union - toponyms - Soviet propaganda - onomastics

\section{Introduction}

Having established their power in the Eastern European countries (Ukraine, Belarus) and Russia and after the following creation of the USSR (Union of Soviet Socialist Republics) in 1922, the Bolsheviks attempted to construct the basis of a new Soviet communist cultural identity. Soviet propaganda 
effectively applied diverse symbols and narratives of the past-and not exclusively of the communist past-by rethinking their meanings and connotations in order to promote its own historical narrative, both in science and within public space. ${ }^{1}$ Re-approaching, re-thinking and further inventing the heroes from the past (including the Greek-Roman history) in the 1920 os became one of the methods to confirm that the proto-communist narrative already existed within the ancient "proletariat". Therefore, Soviet scholars could foster the argument circling around two primary points: that communism indeed has deep roots in the world's history and that the "class struggle" was a decisive factor for the development of the society for at least 2000 years. Classical antiquity, comprising of ancient Greek and Roman history, in the imagination of Soviet state-builders could be used successfully to justify specific communist claims from a historical perspective, serving the particular Soviet myth-making.

For the emergence of these narratives and the development of them into a Soviet grand-narrative, it was required to find relevant points in history that could prove Soviet endeavors. Before that, the nineteenth and early twentiethcentury imperial universities were considered as notable centers of several scientific schools of antiquity, uniformly in history and the classical languages, namely in Petrograd (St. Petersburg), Kyiv, Moscow and Kharkiv. ${ }^{2}$ However, since the 1920 s the cleavage between Marxist history-writing and Western historians became fully aggregated: historical representation of the past in the history-writing started to be artificially integrated into the Marxist doctrine and was thus treated in communist terminology and concepts. ${ }^{3}$

Soviet propaganda of the 1920 and 1930 s has received rich scholarly attention. In 1932, Howard Woolston published his own experience from visiting the USSR where he outlined diverse methods of Soviet propaganda within the public sphere and education, although without mentioning any particular practices, rather his general observations. ${ }^{4}$ Scholars simultaneously emphasize the symbolical importance of toponyms, theatre, mass performances and literature for the Soviets, especially in the early 1920 s when their power was already secured yet the authority required further legitimization. ${ }^{5}$

1 Evgeniy Chiglintsev, "Antichnost v bolshevistskoy propagande pervyih posleoktyabrskih desyatiletiy," Uchenyie zapiski Kazanskogo universiteta. Seriya Gumanitarnyie nauki 151, no. 2-2 (2009): 184-185.

2 Wolfgang Zeev Rubinsohn, Der Spartakus-Aufstand und die sowjetische Geschichtsschreibung (Konstanz: Universitätsverlag, 1983), 13.

3 Rubinsohn, Der Spartakus-Aufstand, 13-14.

4 Howard Woolston, "Propaganda in Soviet Russia," American Journal of Sociology 38, no. 1 (1932): 32-40, www.jstor.org/stable/2767340.

5 Natalia Murray, "Street theatre as propaganda: mass performances and spectacles in Petrograd in 1920," Studies in Theatre and Performance 36, no. 3 (2016): 230-235, https://doi .org/10.1080/14682761.2016.1188262; Irina Gutkin, The Cultural Origins of the Socialist Realist 
The image of Spartacus is one of the most eloquent examples in the history of the Soviet classical reception since it became the most frequently used figure from the antiquity, notable because of the popular sports competitions. Analyzing the perception of Spartacus, as well as the other figures of the classical antiquity, could bring interesting insights regarding the motives of Soviet propaganda. Considering the relevance of Soviet toponymic and onomastic practices for some post-Soviet republics today, such investigation could also serve for a broad comparative perspective.

In my article, I aim to trace the shifts in the perception of Spartacus's rebellion and his figure in the early Soviet era, particularly before the wwII (World War II) and briefly_in the 1950s-196os with a focus on Soviet Ukraine and Soviet Russia. In order to stress the implications of these changes, I will briefly attach further developments in socialist Central-Eastern European countries after WWII. From the very beginning I outline a primary research question: was it Soviet historiography that established the image of Spartacus in the early Soviet republics or rather Soviet history-writing was forced to follow the artificial pathway of Spartacus's image, created by the communist art, toponymic practices and sport? To rephrase, what was more influential in this particular case of the Communist myth-making? This finding would highlight the practice of early Soviet myth-making and reveal the crucial connection between Soviet culture, history-writing and public space.

To organize my study, I will consider essential parts of cultural life that simultaneously influenced the public space: sport and toponymy. The cultural aspect of Spartacus's image is usually defined within the concept of "socialist realism", but the possible art analysis would cross the borders of art history. ${ }^{6}$ In the overview of Soviet historiography I will deliberately omit the historiography discussions about Spartacus in the mid-193os, elaborated in research by Wolfgang Rubinsohn and Sergey Krikh. ${ }^{7}$

Although the promoted figure of Spartacus was a minor component of Soviet propaganda, my article may prompt further research into the tools of promoting the communist narrative inside Soviet republics before 1939 and in the socialist countries of Central-Eastern Europe after 1945. Ultimately, the

Aesthetic: 1890-1934 (Evanston, Illinois: Northwestern University Press, 1999), https://www .jstor.org/stable/j.ctv47w9ij; Kirill Demyanov, Valentina Ryzhenko, "Ideologiya, toponimika, politika pamyati: o massovom pereimenovanii gorodov v SSSR," Vestnik Omskogo universiteta. Seriya «Istoricheskie nauki » 16, no. 4 (2017): 155 .

6 Gutkin, The Cultural Origins, 38-39.

7 See Rubinsohn, Der Spartakus-Aufstand; Sergey Krikh, "A.V. Mishulin i ego Spartak," Vestnik drevney istorii 292, no. 1 (2015): 178-189. As I demonstrate further, that discussion was more focused not on the myth-making, but on the correlation with current party approaches. 
scope and the approach of my article lie within diverse fields: early Soviet history, history of propaganda, art history and the classical reception studies.

\section{Inventing the Hero in Early Communist Propaganda}

The hero myth-making in the early Soviet republics should be placed into a broader context. ${ }^{8}$ The early Soviet republics here are understood as the national republics under the Bolshevik power. How could the co-existence of the national republics within the USSR and the international friendship narrative affect the creation of the heroic Spartacus's myth and vice-versa if it is acknowledged that there was "no national culture" in the USSR at that period? ${ }^{9}$ Yuri Slezkine argues that the national republics were used for promoting the Bolshevik ideals in order to "overcome national distrust and reach national audiences". ${ }^{10}$ Neglecting Spartacus's ethnicity in toponymy or sport, although acknowledged in later history-writing, was a reflection of a contradictory Soviet approach towards the national republics in the 1920s. Promoting an international hero in the "national" era of the Soviet republics conflicted with internal Soviet politics, but corresponded the celebrated idea of "Friendship of the people", thus the image of Spartacus was employed more in the 193os after the change of the Soviet narratives. ${ }^{11}$

The 1930s witnessed a turn in national policy. During the 1930s, the "national Russian iconography" that was "headed principally by Alexander Pushkin" emerged along with the national iconical figures of Ukraine, Armenia, and other republics. ${ }^{12}$ These icons became the rivals of the internationalized figure of Spartacus within the national dimension. From the other perspective, in 1929-1930 USSR initiated a socialist competition that comprised over 2 million workers, "a mass-production movement, mobilized by the party-state". 13

8 For the discussion on the national republics see Yuri Slezkine, "The USSR as a Communal Apartment, or How a Socialist State Promoted Ethnic Particularism," Slavic Review 53, no. 2 (1994): 417-420, https://doi.org/10.2307/250130o and on the role of history see David Brandenberger, National Bolshevism: Stalinist Mass Culture and the Formation of Modern Russian National Identity, 1931-1956 (Cambridge, MA: Harvard University Press, 2002), 6-9, 29-48.

9 Slezkine, "The USSR," 435.

$10 \quad$ Slezkine, "The USSR," 420.

11 Slezkine, "The USSR," 443.

12 Slezkine, "The USSR," 443, 446; Brandenberger, National Bolshevism, 29.

13 Kenneth M. Straus, Factory and Community in Stalin's Russia: The Making of an Industrial Working Class (Pittsburgh: University of Pittsburgh, 1997), 139-140. 
The socialist working competition was an integral partner of the sport competition, and in both of them the image of a strong man (rarely-a woman) prevailed. ${ }^{14}$

Along with Spartacus in the Soviet era, other figures from the antiquity were represented in the public scope (especially during the first years after the 1917 coup): Marcus Junius Brutus, the murderer of Caesar, and Tiberius Sempronius Gracchus, the tribune of the people and initiator of agrarian reforms in 133-132 B C. Gracchus in the 1920 became Spartacus's original counterpart in the toponymy and interest of the historians, although Spartacus "won" this battle. ${ }^{15}$ This happened due to the mythical historical nature of Spartacus's figure and the issue of military resistance against Romans, what was later interpreted in historiography as a "revolution of the slaves". A common characteristic for each of the Roman figures was the use of force in the competition for their own interests, albeit with different motives-Gracchus as a tribune, who planned to re-assemble for a second term contrary to the Roman law, Spartacus as a gladiator who was unlikely to have other optional actions, and Marcus Brutus as a "fighter against tyranny". Similarly, considerable attention in the Soviet history-writing in the mid-twentieth century was paid to the examples of revolutions, revolts and riots in world and Russian history. ${ }^{16}$

Spartacus was not given significant attention from the Marxist thinkers. The frequently mentioned quotation from Marx's letter to Engels (27.02.1861) is that Marx, while reading Appian's Civil Wars deduced that "Spartacus in his (Appian's-author) imagination is represented as the most outstanding guy (paren' in Russian translation-author) in the whole ancient history. A great commander (not to be compared to Garibaldi), a noble character, a

14 I elaborate the point about the masculinity of Spartacus, kindly advised by an anonymous reviewer of my article in the section about sport.

15 Rubinsohn, Der Spartakus-Aufstand, 11.

16 In 1948, the winner of the Stalin Prize for his work on the Peasant War in Germany and the role of Thomas Müntzer was Moses Smirin, in 1950-Ivan Smirnov for his work on the uprising of Bolotnikov and Boris Porshnev for the study of uprisings in France before the Fronde, in 1952-Jan Krastin for the study of the 1905 revolution in Latvia. Soviet history-writing since the 1920 semphasized the importance of the 1917 revolution in terms of historical progress, comparing the events of 1917 with the French Revolution, finding deep analogies and socialist grounds of the latter. This served two primary points: demonstration of a revolutionary precedent and, therefore, proving the legitimacy of Bolshevik approaches, applied in the Soviet republics. For elaboration see a recent monograph by Jay Bergman, The French Revolutionary Tradition in Russian and Soviet Politics, Political Thought, and Culture (Oxford: Oxford University Press, 2019), 51-30o and the chapter "Mythologizing the New Soviet Regime". 
genuine representative of the ancient proletariat."17 Much greater attention to Spartacus and his revolt was paid by the Bolsheviks because of the name of the German Marxist organization dating back to the period of the World War I-Spartakusbund (Spartacus League). ${ }^{18}$ The motives for choosing the name by German Marxists could as well be symbolic-Spartacus was perceived as the leader of the suppressed, and Lenin's speech in 1919 justified their choice as they were "the only German party which is really fighting against the yoke of capitalism."19 This raises a further problem: did the Soviet toponymy reflect the devotion to Spartacus himself or rather to the Spartacus League? Further "elevation" of Spartacus in Communist propaganda was from then on based on this continuation between antiquity and the modern Communists, both German and Soviet. ${ }^{20}$ Lenin likewise briefly mentioned Spartacus in his works. ${ }^{21}$ The conjunction of recent Marxist history with Spartacus's fitting within the Communist narrative anticipated his inclusion into the public space of the Soviet republics.

On the 2nd August, 1918, Izvestiia published a list of the historical figures whose monuments should be erected in the near future across Soviet Russia (one should bear in mind that this list was, in fact, relevant for other Soviet republics as well). ${ }^{22}$ This became pivotal for the future of Spartacus's figure in the Soviet states. Spartacus gained the first place in the aforementioned list, allocated within the range of "revolutionists and community leaders." ${ }^{23} \mathrm{On}$ the contrary to two ancient Romans (Gracchus and Brutus), Spartacus would now be representing the suppressed stratum of the Roman state- the slaves. Interestingly, no ancient Greek political or military leader was included. This list was anticipated by the April's "Decree on the Monuments of the Republic." ${ }^{24}$

17 All translations are mine, unless otherwise indicated. See Karl Marks, Fridrih Engels, Sochineniya. Tom 30 (Moskva: Izdatelstvo politicheskoy literatury, 1963), 125-126.

18 Aleksandr Mishulin, Spartakovskoye vosstaniye. Revolyutsiya rabov v Rime v I v. do nashey ery (Moskva: Sotsialno-ekonomicheskoye izdatelstvo, 1936), 103-104.

19 Vladimir Lenin, "The State: A Lecture Delivered at the Sverdlov University," trans. George Hanna, in Lenin's Collected Works, 4th English Edition, Vol. 29 (Moscow: Progress Publishers, 1972), 470-488, https://www.marxists.org/archive/lenin/works/1919/jul/11.htm.

$20 \quad$ Rubinsohn, Der Spartakus-Aufstand, 9.

21 Lenin, "The State," 470-488.

22 "Spisok lits, koim predlozheno postavit monumenty v g. Moskve i drugikh gorodakh RSFSR," Izvestiya VTsIK, no. 163 (427), August 2, 1918, https://runivers.ru/philosophy/ chronograph/406544/; Richard Stites, Revolutionary Dreams: Utopian Vision and Experimental Life in the Russian Revolution (New York-Oxford: Oxford University Press, 1989), 89. Stites, Revolutionary Dreams, 111.

24 "12 aprelya. Dekret o pamyatnikakh Respubliki”, Elektronnaya biblioteka istoricheskikh dokumentov, accessed March 18, 2020, http://docs.historyrussia.org/ru/nodes/14663-12aprelya-dekret-o-pamyatnikah-respubliki\#mode/inspect/page/2/zoom/4. 
The heroes of the "Plan of Soviet monumental propaganda", as N. Shalaeva noted, “... personified to a greater or lesser extent the fight against tyranny and had to embody the background of the struggle of impoverished, humiliated and insulted for their rights and freedom, for the bright future."25 S. Michalski identified the reasons for choosing Spartacus and other people from the list as they were the "left-wing antecedents" of the Communists, or, as J. Bergman wrote- "the precursors of the Bolsheviks". ${ }^{26}$

The "Soviet period" of Spartacus commenced almost immediately. In 1920 was first staged the play Spartak by V. Mazurkevich, the tragedy by $\mathrm{V}$. Volkenshteyn was published in 1921 and performed in the Moscow Theatre of Revolution in $1923 .{ }^{27}$ The most beloved examples of mass propaganda in recent studies are the street theaters and mass performances. The Mystery of Liberated Labour, performed in Petrograd in 1920 embodied the figure of Spartacus along with seventeenth-century rebel Stenka Razin: "Time and space were relative and Roman slaves led by Spartacus ran towards red banners, followed by peasants with Stenka Razin ahead of them ... In the grand finale, the Kingdom of Socialism was revealed in the form of a rising sun."28 Spartacus and his rebellion were thus symbolizing the struggle for the future Kingdom of Socialism, associated perhaps with Soviet Russia or with the state to emerge after the world socialist revolution. I have not found any evidence of orders from the ruling leaders to the authors regarding the proper description of Spartacus, hence I assume that the general Spartacus image was already present in the popular imagination in the early 1920s, shaped by the mentions in the official documents and idealised description by Marx.

A peculiar catalyst for the interest in Spartacus for non-historians was the publication in the USSR the historical novel by Raffaello Giovagnoli, Spartaco, written in 1874 and the film Spartak, directed by Ertuğrul Muhsin Bey in 1926 in Odesa, demonstrated in 1926 in Kyiv and in 1928 in Moscow. ${ }^{29}$ According to the analysis of the electronic catalogue of the largest university library of

25 Nadezhda Shalayeva, "Plan sovetskoy monumentalnoy propagandy: problemy realizatsii. 1918-1921 gody," Vestnik Chelyabinskogo gosudarstvennogo universiteta. Istoriya 337, no. 8 (2014): 33 .

26 Sergiusz Michalski, Public Monuments. Art in Political Bondage 1870-1997 (London: Reaktion Books, 1998), 108-112; Bergman, The French Revolutionary Tradition, 221.

27 Evgeniy Chiglintsev, "Antichnost v bolshevistskoy propagande pervykh posleoktyabrskikh desyatiletiy," Uchenyye zapiski Kazanskogo universiteta. Seriya Gumanitarnyye nauki 151, no. 2-2 (2009): 185-186.

28 Murray, "Street theatre," 235-236; Gutkin, The Cultural Origins, 6o-61; Moreover, in 1956, the ballet "Spartacus" was created, which became popular in many scenes of the USSR.

29 "Spartacus", VUF KU (All-Ukrainian Photo Cinema Administration), accessed May o9, 2020, https://vufku.org/en/lost/spartacus/. 
Ukraine (The Maksymovych Scientific Library), it is known about at least two dozen different editions of Giovagnoli's book. ${ }^{30}$ Similar editions are available in the collections of the largest library of Ukraine and the National Library of Belarus in Minsk. ${ }^{31}$ Such a drastic increase in the number of publications about Spartacus actually correlated with the fresh image of the 1917 revolution and the Soviet narrative, in which ordinary workers and peasants overcame the existing system. However, one of the documents from the Stalinist era mentions two facts: that "All of us in the past became engrossed in our youth with books like Giovagnoli's Spartaco" but also that "... in 1932 the Institute of Literary Criticism and Bibliography faulted this book." ${ }^{32}$ Nevertheless, Giovagnoli's book along with some others was oriented on the "conscious workers" as "the countless socialist fairy tales that were read to them, or which they read, on the evils of capitalism, autocracy, and religion and the beauties of a coming order of equality under socialism."33 Spartacus's story clearly demonstrated that nearly two thousand years ago similar events occurred in ancient Rome.

The film Spartacus (1926), unfortunately, has not survived, and the fate of its perception was specific. ${ }^{34}$ The first account of the actual filming of Spartacus dates back to 1926 and is generous in its description. It acknowledges the references towards Giovagnioli's Spartaco and says that "the film draws a famous rebellion of the gladiators with Spartacus as the leader against Rome, patricians and senators". ${ }^{35}$ However, a newspaper article from 1928 strikingly critisizises

30 The editions were published in 1924, 1930, 1936, 1937 (two issues, Moscow and Kharkiv-Odesa), 1947, 1950, 1951, 1954 (two issues, Kyiv and Moscow), 1962, 1968, 1976, 1977 (two issues, Alma-Ata and Grozny), 1978 (two issues, Minsk and Moscow), 1979, 1980, 1981, 1983, 1987, 1988, 1991. See The Maksymovych scientific library, Taras Shevchenko National University of Kyiv. Electronic catalogue, accessed March 18, 2020, http://www.library.univ .kiev.ua/ukr/elcat/new/result.php3?source $=1 \&$ title $=\% \mathrm{D}_{1} \% \mathrm{EF} \% \mathrm{EO} \% \mathrm{Fo} \% \mathrm{~F}_{2} \% \mathrm{Eo} \% \mathrm{EA} \& \mathrm{di}$ $\mathrm{v}=0 \&$ docType $=24 \&$ docType $1=8 \&$ docType $2=17 \&$ docType $3=13 \&$ docType $4=14 \&$ docType $5=$ $15 \&$ docType $6=26 \&$ docType $7=18 \&$ docType $8=19 \&$ docType $9=25 \&$ parentId=o\&qtype $=\&$ pr ev $=75 \&$ page $=0$ \& count $=113 \&$ sort $=$.

31 Vernadsky National Library of Ukraine in Kyiv. Electronic catalogue, accessed March 18, 2020, http://nbuv.gov.ua/. The National Library of Belarus in Minsk. Electronic catalogue, accessed March 18, 2020, http://e-catalog.nlb.by/.

32 Lewis Siegelbaum and Andrei Sokolov, Stalinism as a Way of Life. A Narrative in Documents (New Haven and London: Yale University Press, 2000), 83.

33 Stites, Revolutionary Dreams, 31.

34 VUFKU (All-Ukrainian Photo Cinema Administration) that existed from 1922 to 1930 was responsible for producing "the revolutionary cinema", but was later dissolved. Its legacy is now stored at the website https://vufku.org/en/home/, accessed May o9, 2020. Although the film is not accessible, some frames, posters and reviews of Spartacus are still available.

35 "Spartacus," Kino, no. 9 (1926), vUFKU, accessed May o9, 2020, https://vufku.org/wpcontent/uploads/2018/12/Kino-9-nomer-1926.pdf. 


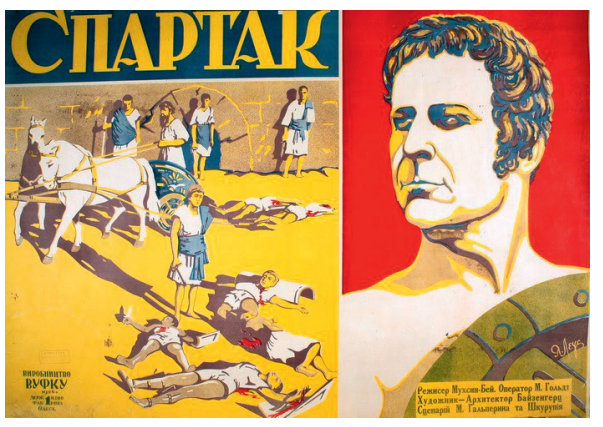

FIGURE 1

Spartacus film poster (1926)

https://vufku.org/lost/spartak/

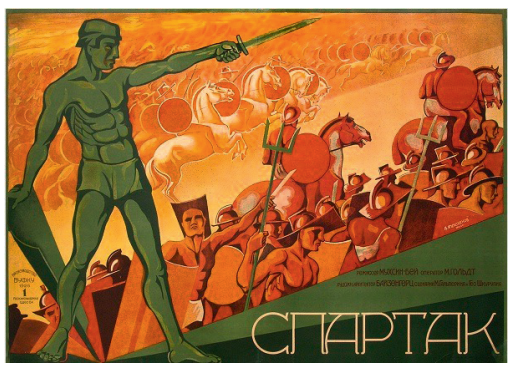

FIGURE 2

Spartacus film poster (1926)

https://vufku.org/lost/spartak/

the film, noting that "Operatic, posturing Spartacus, the insurrection of gladiators and slaves simplified to nonsense ...-all is false. Everything is taken simple-minded, even without irony or humor, from the archives of poor spectacles ...." ${ }^{36}$ Another article from 1929 condemns attempts to introduce operas into Soviet cinematography, underlining the artistocratic features of opera. It hints at the film Spartacus when describing "Historical film with 'hundreds of thousands' of participants, with plenty of opera effects attracts the viewer and almost always is designed for commercial screen ... From that derive thousands of mistakes, thousands distortions of the material itself ...". ${ }^{37}$ The article finishes with a prosaic conclusion: "Cinematography is afraid of opera. Do not let opera in cinematography! Beat its hands!".38 This opposition against

36 Hris. Hersonskiy, "Cinema. vUFKU at the break," (1928), vUFKU, accessed May o9, 2020, https://vufku.org/wp-content/uploads/2019/og/Presa-pro-spartak.pdf. The name of the article is eloquent: 1929 was considered the year of "The Great Break" in Soviet economics, finishing the era of the New Economic Policy.

37 L. Frenkel, "Kino-opery," Kino, no. 1 (1929), vUf KU, accessed May o9, 2020, https://vufku .org/wp-content/uploads/2019/og/Kino-1-nomer-1929.pdf.

38 Frenkel, "Kino-opery". 
aristocratic opera influenced the perception of Spartacus: the film was condemned and the memory about it obliterated. ${ }^{39}$

Seen from this perspective, I may suppose that the reception of Spartacus and the representation of him as a proto-communist hero began in literature and art in the 1920s, followed by the historians in the 1930s. However, it is necessary to enquire whether the figure of Spartacus was well-investigated by the emerging Soviet historiography. The Communist perspective influenced the representation of the rebellion and its aims, and after a brief historical discussion they were delineated accurately. Moreover, the need of reframing Spartacus's image within history-writing simultaneously reflected the new internal and external circumstances of Soviet authorities.

Spartacus in Soviet Historiography

During the 1920s, when the Soviet Marxist historiography was emerging, the first monographs on the topic of Spartacus rebellion were published by Ye. Kagarov and A. Mihaylov. ${ }^{40}$ M. Putilovskiy in 1929 published a fiction book for children about Spartacus. ${ }^{41}$ This period is often known as "co-existence" between the Marxist and non-Marxist doctrines, however, it was merely a transitional time. ${ }^{42} \mathrm{~S}$. Rubinsohn defines several crucial periods in the early Soviet Classics: 1921-1927 was a period of relative tolerance or "the time of 'the old specialists" while 1927-1934 was the "attack of the Marxists." ${ }^{33}$ Hence, between 1924 and 1927 appeared at least two historical monographs on Spartacus

39 One of the plot-writers, Ukrainian poet Geo Shkurupii, was repressed in 1937. Difficult history of Ukrainian cinematography continues. Dovzhenko-Centre, an art and research institution that today stores the production of VUFKU claimed that it went bankrupt in May, 2020 because of lack of government funding.

40 Yevgeniy Kagarov, Spartak. Ego zhizn i borba, (Kharkiv, 1924); Sergey Krikh, Drugaya istoriya: «Periferiynaya » sovetskaya nauka o drevnosti (Moskva: Novoye literaturnoye obozreniye, 2020), 26-27; Klavdiya Korzheva, "Vosstaniye Spartaka v sovetskoy istoriografii," Voprosy istorii, no. 1 (1974): 118-134. For the analysis of the Soviet school textbooks see a recent article: Sergey Krikh, "Spartak v tsitatakh 'klassikov' na stranitsakh sovetskikh uchebnikov," in Omskiye nauchnyye chteniya-2019. Materialy Tretyey Vserossiyskoy nauchnoy konferentsii, ed. P. Prudnikov (Omsk: Izdatelstvo Omskogo gosudarstvennogo universitetata, 2019), 262-264.

41 Mikhail Putilovskiy, Spartak. Vozhd vosstavshikh rabov (Moskva: Krestianskaya gazeta, 1929).

42 Rubinsohn, Der Spartakus-Aufstand, 10, 13.

43 Rubinsohn, Der Spartakus-Aufstand, 48. 
that were bearing simultaneously symbolic propagandist connotations, yet Spartacus was still not in the focus of Soviet historians.

The shift occurred in 1929 when one of the Lenin's texts ("The State: A Lecture Delivered at the Sverdlov University") was published. ${ }^{44}$ There Lenin referred to Spartacus in a way naming him "one of the most prominent heroes of one of the greatest revolts of slaves", leader "of a vast army" during the "widespread uprising of slaves." ${ }^{55}$ Finally, as "such civil wars mark the whole history of the existence of class society", Lenin named Spartacus's rebellion "an example of the greatest of these civil wars in the epoch of slavery."46 This statement shaped the image of Spartacus: he was now represented as a leader of the greatest slave rebellion in the world history during the epoch of slavery, the first stage in the Marxist social formation theory. ${ }^{47}$

The situation unfolded dramatically after 1933. In February of that year, Stalin gave a speech at the congress of collective farmers. In his speech, among the patterns of unsuccessful revolutions in the world history, he claimed that "the revolution of the slaves eliminated slaveholders and abolished the slaveowning form of exploitation."48 It was unlikely that Stalin planned to influence future history-writing in such a way since after the reorganization of the higher education the possibility of a scientific opposition was substantially narrowed and the attempts of discussions with the Marxist theory of formations were significantly limited. However, the Soviet scholars of antiquity (namely, Aleksandr Mishulin and Vladimir Sergeyev) perceived this and several subsequent performances (dated 1934, Stalin's 1938 publication) as a specific instruction. ${ }^{49}$ It is worth mentioning that the vast majority of historians of antiquity from the pre-revolutionary era had either emigrated prior to this time or have agreed with the Soviet approach to the historical processes, particularly because of the "non-tolerance" in history-writing towards all non-Marxist approaches after $1927 .{ }^{50}$

The motivation of historical interest towards the history of antiquity comprised two approaches: firstly, various prizes, awards and the possibility of

44 Pravda, no. 15, January 18, 1929; Rubinsohn, Der Spartakus-Aufstand, 14.

45 Lenin, "The State," 470-488.

46 Pravda, no. 15, January 18, 1929; Lenin, "The State," 470-488.

47 Mishulin, Spartakovskoye vosstaniye, 102; Aleksandr Mishulin, Spartak (Moskva: Uchpedgiz, 1950), 4.

48 Sergey Krikh, "Obraz drevnosti v sovetskoy istoriografii: konstruirovanie i transformatsiya" (Doctor of Historical Sciences diss., Omskiy Gosudarstvennyy Universitet im. F.M. Dostoyevskogo, Omsk, 2015), 187-188.

49 Krikh, "Obraz drevnosti", 187-188; Rubinsohn, Der Spartakus-Aufstand, 14-15.

50 Rubinsohn, Der Spartakus-Aufstand, 10, 13-14. 
career growth. Secondly, it included the atmosphere of subordination of scholarship to the needs of the state and the party and the risk of disagreement with the dominant dogmas. As S. Krikh writes, “... the political culture in the country (USSR - author) has developed in such a way that it was precisely the leading politicians who were considered to be the leading theoreticians of Marxist science, and their expressions on political themes were most often seen as direct references to how to write a story." ${ }^{11}$ In fact, direct instructions from either Stalin, the party or the Academy of Sciences in the case of Spartacus (as well as other historical figures) were not issued as the impact on the standards of historical writing was carried out rather through the hints and dominating atmosphere of fear. The 1930s were also marked by a change in the attitude towards history as a discipline. In September 1931, history was reintroduced as an "independent classroom subject". 52 Soon the "... unsatisfactory nature of existing history textbooks was ... generally recognized", and history as a discipline found itself "at the center of the party hierarchy's ideological agenda" and as "one of the main outposts on the ideological front". ${ }^{33}$ Spartacus's rebellion was merely one battle on those fronts.

After Stalin's speech in 1933 and his ideas regarding the "revolution of the slaves", a peculiar historiographical vacuum on the history of the slave rebellions arose. ${ }^{54}$ While the general, not-detailed direction of history-writing was given from above, Soviet scholarship could not yet draw on an already established academic body of work with regard to ancient slave rebellions. Although Stalin did not directly mention Spartacus in his speech, the need to find a specific example of an ancient revolution led to choosing Spartacus's uprising as an ideal example of this narrative since Spartacus was already represented in Soviet literature, theatre, art and toponymics. Furthermore, in analogy to forced industrialization in Soviet Russia commenced the "forced history-writing". Aleksandr Mishulin, who had previously published articles about ancient India, Egypt, Assyria-Babylonia, ancient Greece and Rome, became the first notable author in the field of Spartacus's story, in particular in

$5^{1} \quad$ Sergey Krikh, "Sistema sovetskoy istoriografii: osnovnyie aktoryi i silyi vliyaniya," Voprosy istorii, no. 7 (2016): 165 .

52 Brandenberger, National Bolshevism, 30-31, 45-47.

53 Brandenberger, National Bolshevism, 37, 45-46; Oksana Klymenko, "Soviet Ideology in Workers' Memoirs of the 1920s-1930s (A Case Study of John Scott's and Borys Weide's Memoirs)," Kyiv-Mohyla Humanities Journal, no. 3 (2016): 46-47, http://dx.doi .org/10.18523/kmhj73934.2016-3·37-55.

54 I.V. Stalin, "Speech at the First All-Union Congress of collective farmers-shock-workers, February 19, 1933,", accessed May 9, 2020, https://www.marxists.org/russkij/stalin/tı3/ t13_39.htm. 
the popular science journal Fighting Classes, later renamed Historical Journal. After the change of the attitude of historians towards Spartacus, the evidence of his actual commitment to the communist ideals began to be investigated in the writings of Marx and Lenin. ${ }^{55}$ Soviet historians mentioned that Marx's short notes of "the great revolutionary of antiquity to be the basis of research on Spartacus" whilst Lenin also "develops and complements Marx's statements about Spartacus." ${ }^{56}$ This, de facto, determined the direction of further Soviet history-writing about Spartacus. ${ }^{57}$

In short, the historiographical aspect was grounded in the creation of Spartacus's image as a hero of ancient history and an illustration for further imitation. In this context, it is essential to compare the works of 1936 and $195^{\circ}$ (posthumous edition) by Aleksandr Mishulin, one of the most prominent Soviet historians of ancient Rome. Already in 1936, Mishulin's book mentioned the "Spartacus's revolution" along with the word "revolt."58 Up to 1950, he had developed the idea that Spartacus had his own social-political programme (sic!). ${ }^{59}$ S. Utchenko, in concluding the preface to the publication of Mishulin's Spartacus in 1950, wrote that "... we have every reason to consider the greatest revolutionary shake to the foundations of the slave system and one of the most striking manifestations of the struggle of suppressed classes", repeating traditional Soviet cliché. ${ }^{60}$

In 1937, the first issue of the Bulletin of Ancient History (Vestnik Drevney Istorii, VDI), one of the most influential Soviet historical journals on the history of the ancient world, was published. This demonstrated the need for further historical research. The first issue contained the article by A. Mishulin "To the history of the uprising of Spartacus in ancient Rome". ${ }^{61}$ However, in addition to a number of engaging concepts at the beginning of the article ("the revolutionary commitment of slaves and peasants", "a common revolutionary struggle"), further consideration of the materials and sources was carried out by purely historical methods. ${ }^{62}$ Moreover, there are no references either to Marx, Lenin or Stalin - only to the foreign researches and even most recent archaeological

\footnotetext{
55 Mishulin, Spartakovskoye vosstaniye.

56 Korzheva, "Vosstaniye Spartaka," 119-121.

57 Korzheva, "Vosstaniye Spartaka," 121-122.

$5^{8}$ Mishulin, Spartakovskoye vosstaniye, 87.

59 Mishulin, Spartak, 76, 83, 9o.

6o Mishulin, Spartak.

61 Aleksandr Mishulin, "K istorii vosstaniya Spartaka v drevnem Rime," Vestnik Drevney Istorii, no. 1 (1937): 133-142.

62 Mishulin, "K istorii vosstaniya," 133-136.
} 
excavations and publications dating from $1927-1928.63$ Since VDI was oriented specifically on the narrow-profile specialists, historical sources proved to be the most effective means of sharing Soviet ideas. ${ }^{64}$ At the same time, Mishulin in this article argued that Spartacus's army included not only slaves but also free small Italian landowners and claimed that the social disputes caused the split in the army. ${ }^{65}$ His articles about Spartacus date back to 1934, 1935 and 1937 with the monograph published in 1936 which became a specific history-writing ideal in the USSR. His fiction book on Spartacus's figure was printed in 1947. Right after the publication of Mishulin's first work, P. Preobrazhenskiy and A. Sergievsky criticized his "necessary, but raw scientific work." ${ }^{66}$ Nevertheless, Mishulin's books were re-published in 1947 and 1950 with significant circulation across Soviet libraries. ${ }^{67}$

The study of the history of slave-owning relations as it was named in Soviet historical scholarship continued to develop in the 1950s-6os. At this time, the articles and works are published by E. Shtaerman, G. Shrot, S. Kovalev, S. Utchenko and S. Zhebelev, arguing about dating and the causes of the defeat of Spartacus, the potential siege of Rome, the social structure of the uprising. ${ }^{6}$ However, the general image of Spartacus, constructed by A. Mishulin in the 1930s - even though questioned-remained almost unchanged throughout further Soviet history-writing. Therefore, the period of the 1930s became decisive for the further existence of the image of Spartacus and the Marxist view of his role in the history of the ancient world. The same was valid for the scientific substantiation of the use of Spartacus's name and image in the cultural and sport aspects of Soviet reality. ${ }^{69}$

The attention towards Spartacus arose in the mid-192os and flourished during the historical discussion of the 1930s. But in fact, Soviet historians during the 1920 s first had to establish a myth about Spartacus in order to promote another myth about his antecedence of the communist ideas. As I will demonstrate in the following sections, these endeavors were outstripped by Soviet toponymy and sport practices.

\footnotetext{
63 Mishulin, “K istorii vosstaniya," 133-142.

64 Moreover, A. Mishulin was the chief editor of VDI in 1938-1948.

65 Mishulin, "K istorii vosstaniya," 134, 137-139.

66 Petr Preobrazhenskiy, "Retsenziya.: Mishulin A.V. Spartakovskoe vosstanie," Istorikmarksist, no. 6 (1936): 207-208. Preobrazhenskiy was repressed in 1937 and shot in 1941 because of "counterrevolutionary activities". Korzheva, "Vosstaniye Spartaka," 121, 124.

67 Krikh, "A.V. Mishulin," 178-189.

68 Korzheva, "Vosstaniye Spartaka," 123-129.

69 See also a recent monograph by Krikh, Drugaya istoriya.
} 
Toponymy was another effective tool of Soviet propaganda, and in the context of recent decommunization processes in Ukraine, it requires much deeper enquiry. ${ }^{70}$ Renaming of the streets, squares or cities was usually dedicated to particular anniversaries or dates - the fifth or tenth anniversary of "the Great October" (1917 revolution), Lenin's death (1924) or its anniversary, military victories (e.g. Siege of Perekop). ${ }^{71}$ Before $1923-1924$ the toponymic situation in the Soviet republics remained relatively chaotic, only since 1920 or even 1924 "the authorities were deliberately pursuing the policy of implementing the cult toponymy in the territory of the whole Soviet Union." ${ }^{72}$ Its main aim was the "political enlightenment of the society" with further promotion of the Communist narrative as the only one that was indeed fitting the future of the people. ${ }^{73}$ Strict regulations developed during the 193 os but predominantly they were considering the names of the settlements, so the street naming remained under the control of local authorities and party. ${ }^{74}$

Unfortunately, no database includes the history of Soviet renaming of the city toponyms, for instance streets or avenues. ${ }^{75}$ The only information is allocated either in the local archives or in the city guides and handbooks,

70 For instance, there are thoughts that in the provinces of the USSR existed "a system of special symbolic gradation, a system which catered to visual expectations". It is a very interesting suggestion. Might it imply that only specific cities could bear the name of the Soviet leaders? Maybe this is the reason why the villages named after Spartacus were rather an exclusion than the rule? So far, I have found information only regarding the village Spartacus (Spartak) in Donetsk region that was established in c. 1922-precisely in the Soviet period thus it did not have any "historical name" before. See Michalski, Public Monuments, 118-119.

71 Sergey Nikitin, "Revolyutsiya i geografiya," Otechestvennyye zapiski, no. 2 (2003), accessed 18.02.30, https://magazines.gorky.media/oz/2003/2/revolyucziya-i-geografiya.html.

72 Peter Kenez, The Birth of the Propaganda State (Cambridge: Cambridge University Press, 1985), 123, https://doi.org/10.1017/CBO9780511572623; Demyanov and Ryzhenko, "Ideologiya, toponimika," 155; Myroslav Borysenko, "Toponimika Ukrainy 1920-1930-kh rokiv (istorychnyi analiz)," Etnichna istoriia narodiv Yevropy, no. 8 (2001): 22, http://irbisnbuv.gov.ua/cgi-bin/irbis_nbuv/cgiirbis_64.exe?I21DBN=LINK\&P21DBN=UJRN\&Z21ID= $\& \mathrm{~S}_{21} \mathrm{REF}=10 \& \mathrm{~S}_{21} \mathrm{CNR}=20 \& \mathrm{~S}_{21} \mathrm{STN}=1 \& \mathrm{~S}_{21} \mathrm{FMT}=\mathrm{ASP} \_$meta\&C21COM=S\&2_S $21 \mathrm{Po} 3=$ FILA $=\& 2 \_S 21 S T R=e i n e \_2001 \_8 \_7$.

73 Benno Ennker, Formirovaniye kulta Lenina v Sovetskom Soyuze, trans. Aslan Gadzhikurbanov (Moskva: ROSSPEN, 2011), 64.

74 Borysenko, "Toponimika Ukrainy," 22-23.

75 See the analysis of the city toponymy in Kharkiv and Vynnytsia: Mariia Takhtaulova, "Toponimika ta ideolohiia: zminy u toponimitsi Kharkova v pershi desiatylittia radianskoi vlady," Visnyk Natsionalnoho tekhnichnoho universytetu "KhPI". Ser.: Aktualni problemy istorii Ukrainy 1068, no. 25 (2014): 128-136; Kseniia Kuzina, "Radianska toponimika mist 
published in the intersection of the 1920 and 1930s. In my article, I analyse those from the capital of Ukrainian SSR till 1934 Kharkiv (1929) and two biggest cities: Kyiv (1930) and Odesa (1929). ${ }^{76}$

The handbook from Odesa refers to official institutions and organizations in the city with a description of their territorial allocation. It does not mention Spartakivska street or lane that exist in Odesa today. The Kyiv guide mentions the Spartacus's square twice. ${ }^{77}$ Moreover, it mentions the previous name-Mykolaivska square - that was probably called so after the Russian tsar Nicholas I and this symbolical contrast cannot be ignored: the name of the emperor was obliterated to honor the slave leader. ${ }^{78}$ Spartakivska street, however, appeared in Kyiv only in 1955. Finally, in Kharkiv, it is known about Spartakivska lane which hosted one of the labour communities, Kharkiv County Trade Inspectorate and the postal-telegraph service and was renamed in the gap between late 1918 and $1929 .{ }^{79}$ The hotel Spartak has received its name during the same period reaffirming the hypothesis that Spartacus image was renown in Soviet Ukraine before the 193 os and the historiography discussion. ${ }^{80}$

Meanwhile, the usage of the toponyms named after Spartacus did not become widespread in comparison with other Soviet toponyms used. In 1920, one of Omsk streets received a name Spartakovskaya becoming one of the first known examples. ${ }^{81}$ We record a few names of settlements in Kazakhstan, Ukraine and Russia in the times of the USSR which often date back to the 1920 . Similar situation with the streets was characteristic for Russia (Vladikavkaz, Yekaterinburg, Novosibirsk, Kaluga), Ukraine (Dnipropetrovsk—now Dnipro, Poltava, Donetsk) in the Soviet period. The monuments of Spartacus in the USSR despite the planned project of monumental propaganda were also

yak sposib perepysuvannia istorychnoi pamiati (na prykladi Vinnytsi 1920-30-kh rr.)," Istorychni i politolohichni doslidzhennia, no. 1 (2017): 40-50.

76 Fedir Ernst, Kyiv. Providnyk (Kyiv: 2-ha drukarnia, 1930); Dovidnyk "Vsia Odesa” na 1930 rik. Providnyk u misti y na kurortakh ta medychnyi pokazhchyk (Odesa: Chornomorska komuna, 1929), http://rarebook.onu.edu.ua:8081/handle/store/2455; Adresno-dovidkova knyha "Ves Kharkiv" na 1929-y rik (Kharkiv: Kharpolihraf, 1929), http://elib.shpl.ru/ ru/nodes/33702-na-1929-y-rik-1-y-rik-vidannya-1929\#mode/flipbook/page/1/zoom/3. Unfortunately, smaller Soviet towns and villages did not receive such city handbooks to be representative for the studies on the period.

77 Ernst, Kyiv, 404, 441.

78 Ernst, Kyiv, 779 .

79 Adresno-dovidkova knyha "Ves Kharkiv", 39, 47, 56.

8o Adresno-dovidkova knyha "Ves Kharkiv", 36, 41.

81 Dmitriy Alisov, Olga Gefner, Tatiana Zolotova and Nikolay Khilko, Kulturnyye landshafty sovetskogo goroda: sibirskiye goroda pozdnego sotsializma (Moskva: Institut Naslediya, 2019), 37 . 
absent with just one known in Odesa, Ukraine (erected in 1988) near the stadium Spartak. ${ }^{82}$

Interestingly, one of the villages in Eastern Ukraine obtained the name Spartak in 1922 with a kolkhoz with the same name, established 8 years later. The process of choosing the name is described in an unusual manner: "During the distribution of the land the surveyor proposed to name the farmstead Spartacus that in translation from Greek is 'advanced and invincible." 83 How could the local surveyor know the Greek translation (which is nevertheless false)? Was it because of the dominant image of Spartacus that prevailed in Soviet society in the early 192os? Perhaps, this statement is true since Spartacus was represented as a vigorous military leader first of all, and this idea was later applied in Soviet sports.

Onomastics and personal names became another tool of propaganda. Since the 1920s the male name of Spartacus was introduced along with other socialist names implemented by the Soviets. ${ }^{84}$ Spartacus was used "as the revolutionary name" in one of the first Soviet utopias. ${ }^{85}$ Besides that, the nephew of aforementioned historian A. Mishulin, a well-known actor in the USSR, received the name of Spartacus. There is a list of other famous people with the name Spartacus: scholars (S. Akhmetov, S. Belyaev, S. Kntegchtsyan), athletes (S. Gogniyev, S. Jedzelava), actors (S. Sumchenko, S. Bagashvili) and military officers (S. Zhelezny, S. Makovsky).

The popularity of Spartacus's figure after the first wave of renaming in the Soviet republics in the early 1920 increased drastically after 1933 yet no statistics are currently available, rather the list of the toponyms which require decommunization (in case of Ukraine). Surprisingly, the streets, hotels and lanes, named after Spartacus are not considered in the decommunization process as they are claimed to be renamed in the name of the ancient rebel leader, not

82 Andrii Tarasenko, "« Chto bylo vstar. to povtoritsya snova ... »: Neomifologizm v skulpture A. Knyazika," Khudozhnia kultura. Aktualni problem, no. 4 (2007): 135-136, http:// www.irbis-nbuv.gov.ua/cgi-bin/irbis_nbuv/cgiirbis_64.exe?I21DBN=LINK\&P21DBN=UJ $\mathrm{RN} \& Z 21 \mathrm{ID}=\& \mathrm{~S}_{21} \mathrm{REF}=10 \& \mathrm{~S}_{21} \mathrm{CNR}=20 \& \mathrm{~S}_{21} \mathrm{STN}=1 \& \mathrm{~S}_{21} \mathrm{FMT}=\mathrm{ASP} \_$meta\&C21COM$=\mathrm{S} \& 2$ S21Po3=FILA=\&2_S21STR=khud_kult_20o7_4_12. A theory regarding possible Spartacus's Thracian origins exists, thus this had a special meaning for the Bulgarians.

83 Serhii Dobriak, "Selo Spartak," in Mista i sela Ukrainy. Donechchyna, accessed March 19, 2020, 1, https://who-is-who.ua/main/page/mistadon20o8/95/168.

84 Elena Dushechkina, "Messianskiye tendentsii v sovetskoy antroponimicheskoy praktike 1920-kh-1930-kh godov," Toronto Slavic Quarterly, no. 12 (Spring 2005), http://sites .utoronto.ca/tsq/12/dushechkina12.shtml.

85 Stites, Revolutionary Dreams, 176. 
a German Communist organisation. ${ }^{86}$ This argument was particularly prevalent during the debates in Kharkiv City Council: "Spartacus was the chief and the leader of the slaves during the Third Slave war, a notable slave rebellion against the Roman republic. He was an experienced commander: his army included only the escaped gladiators and slaves and defeated several experienced Roman legions in a series of battles." ${ }^{177}$ This surprisingly deep historical argumentation from a local city council in Ukraine is limited in scope, in that it does not fully explain why Kharkiv (as well as some other Ukrainian cities that decided to circumvent the decommunization laws) did not rename any other city objects to honour other rebels from the ancient history, e.g. from the First or Second Slave uprisings?

Taken together, the series of attempts to rename the streets and city toponyms suggests that the process of renaming was based on the acculturation of Spartacus's figure by German and later-Soviet Communists. Although Spartacus was included on the list of monumental propaganda, it is unknown how many monuments to Spartacus were erected in the 1920s or 1930s. At the same time, during this period emerged the first city objects (streets, squares, lanes, hotels), renamed after Spartacus. He was still visualized as a brilliant military commander of the slave army, but the narrative of the revolution of the slaves was not pursued until the 193os. Considering onomastics and the image of Spartacus as a physically strong figure, the usage of his name was tremendously notable in the field of sport, my last point of interest in the article.

\section{$5 \quad$ Sport and Spartacus in Socialist Reality}

The sports dimension of Soviet propaganda has recently received considerable attention from scholars. ${ }^{88}$ It might seem unclear why exactly Spartacus

86 See the decision of Kharkiv City Council "About renaming the objects of the toponymics of Kharkiv" from 20.11.2015, accessed March 17, 2020, https://www.city.kharkov.ua/ uk/document/pro-pereymenuvannya-obektiv-toponimiki-mista-kharkova-48723.html. Same arguments were applied in Odesa and several other Ukrainian cities where the toponyms named after Spartacus are still viable (Bila Tserkva, Kyiv, Mariupol).

87 Reiestr aktiv Kharkivskoi miskoi rady, "Pro pereimenuvannia obiektiv toponimiky mista Kharkova," 20.11.2015, http://kharkiv.rocks/reestr/644875.

88 Karl Veth, "Selling the People's Game Football's transition from Communism to Capitalism in the Soviet Union and its Successor State" (PhD diss., King's College London, London, 2016), https://kclpure.kcl.ac.uk/portal/en/theses/selling-the-peoples-game(59ee 636c-512d-4904-8159-ed940a570329).html; Karl Veth, "Stalinism—Football and Culture in the Interwar Soviet Union," Futbolgrad, December 31, 2018, http://www.futbolgrad.com/ stalinism-football-soviet-union/; Barbara Keys, "Soviet Sport and Transnational Mass 
was chosen as a prototype of Soviet sportsmanship and an example to follow for the participants within diverse sports competitions. However, when taking into consideration his muscular physique, he became the ideal candidate. The references could be made to his biography: Spartacus participated in the gladiator fights in ancient Rome and was a member of the gladiator school, and later used his physical and military background to lead the gladiators and the slaves in the battles. Most importantly, he proved (in the imagination of Soviet propaganda) that peak physical fitness was not predicated on the participation of the "upper-class" sporting events, such as the Olympics.

The foreign policy of that time confirms my suggestions. Firstly, Soviet team was not accepted for the participation in the restored in 1896 Olympic Games. The Olympics in the perception of the Soviets were a prototype of aristocratic competitions among the Europeans whilst an alternative to the aristocracy was the lower strata of society, "suppressed class", the ideal archetype of which was Spartacus-a man who fought against Roman aristocrats. ${ }^{89}$ Secondly, in 1921, the Red Sport International (Sportintern) was created as an oppositional organization to the International Olympic Committee, which was supposed to serve the interests of the Soviet republics in the sport. ${ }^{90} \mathrm{~A}$ year before, in Lucerne, European Social Democrats, critically-minded about the Bolsheviks, created their own Socialist Workers' Sport International which had to be a "sports opposition" to the Olympics. ${ }^{91}$

In 1924 the USSR received an invitation to participate in the Olympic Games but refused, launching a massive sport movement within the country. As a new type of socialist sport competitions, first Spartakiads were organized by the Youth Sports organization named after Spartacus in Petrograd (laterLeningrad) in 1923. However, there also exists a thought that the very name of Spartakiada was created by Czech activist Jiří František Chaloupecký. ${ }^{92}$

Culture in 1930," Journal of Contemporary History 38, no. 2 (2003): 413-434, https://doi.or g/10.1177/0022009403038003005; Keith Phillis, "Spartacus and Sports in the Soviet Union and Eastern Europe," International Journal of Sport \& Society 3, no. 2 (2013): 37-48; Stefan Rohdewald, "Yugoslavian Sport and the Challenges of Its Recent Historiography," Journal of Sport History 38, no. 3 (2011): 387-395, www.jstor.org/stable/10.5406/jsporthistory.38.3.387.

89 James Riordan, "The sports policy of the Soviet Union, 1917-1941," in Sport and International Politics: Impact of Facism and Communism on Sport, eds. Pierre Arnaud and James Riordan (London: Taylor \& Francis e-Library, 2003), 70.

9o Riordan, "The sports policy," 69-70; Jim Riordan, "Elite sport policy in East and West," in The Politics of Sport, ed. Lincoln Allison (Manchester: Manchester University Press, 1986), 71.

91 Riordan, "Elite sport policy," 71.

92 František Morkes, "Jak vzniklo slovo 'spartakiáda," Český rozhlas Plus, September 24, 2010, https://plus.rozhlas.cz/jak-vzniklo-slovo-spartakiada-6646932. 
J. Riordan stated that "The Spartakiad was intended to demonstrate proletarian internationalism in sport by being a universal worker Olympics and a counterbalance to the bourgeois Olympics being held the same year in Amsterdam." ${ }^{93}$ The first All-Union Spartakiada was held in 1928, in 1930-the First All-Ukrainian Peasant Spartakiada. In the competitions of 1928, were represented the teams of other states, comprising predominantly left activists (Germany, Finland, England, Switzerland, Sweden, France, Uruguay, Czechoslovakia). ${ }^{94}$ Significantly demonstrative was the amount of the participants-c. 7000 participants of the Games against c. 3000 participants of the Olympiad, held the same year in Amsterdam; symbolically, the Summer Spartakiada was launched on the day of the Olympics final day. ${ }^{95}$ The movement of Spartakiads expanded abroad: before the All-Union one, the Winter Workers' Spartakiada was held in Oslo.

The change in Soviet perception of particular historical persons and events was a logical response to the geopolitical and strategic challenges faced by the early Soviet republics and USSR as a unified state structure since 1922. ${ }^{96}$ Therefore, it would be particularly interesting to compare the perception and reflection of ancient heroes along the first decades of Soviets and during the Cold War as then it became a tool of Soviet influence via Soviet satellites in Central and Eastern Europe. ${ }^{97}$

For instance, in 1934 (a year after Stalin's speech), the football club "Promkooperation" was renamed into "Spartacus" (Spartak), having set this trend for many sport teams of the USSR. ${ }^{98}$ The following year, arose the Voluntary Sports Society of the Artels of Industrial Cooperation, which took care of the promotion of sports in the USSR and which in 1937 received

93 Riordan, "The sports policy," 70. A brilliant analysis is provided in Petr Roubal, Spartakiads: The Politics of Physical Culture in Communist Czechoslovakia, trans. Dan Morgan (Prague: Karolinum Press, 2019).

94 Hennadii Butkevych, Oleksandr Shevchenko and Volodymyr Yalovyk, "Alternatyvni olimpiiskomu rukhu zmahannia: robitnychi Olimpiady ta Spartakiady," Fizychne rykhovannia, sport i kultura zdorovia u suchasnomu suspilstvi, no. 4 (2014): 5-11; André Gounot, "Between revolutionary demands and diplomatic necessity: the uneasy relationship between Soviet sport and worker and bourgeois sport in Europe from 1920 to 1937" in Sport and International Politics: Impact of Facism and Communism on Sport, eds. Pierre Arnaud and James Riordan (London: Taylor \& Francis e-Library, 2003), 197.

95 Riordan, "The sports policy," 70.

96 Riordan, "The sports policy," 69-71.

97 A brief overview of early implementation of antiquity into Bolshevik propaganda was conducted by E. Chiglintzev, see Evgeniy Chiglintsev, "Antichnost v bolshevistskoy propagande pervyih posleoktyabrskih desyatiletiy," Uchenyie zapiski Kazanskogo universiteta. Seriya Gumanitarnyie nauki 151, no. 2-2 (2009): 183-188.

98 Veth, "Selling the People's Game," 100-101. 
the Order of Lenin. Sports clubs Spartak emerged in most team sports. More than a dozen of Soviet cities, namely Alma-Ata, Armavir, Kyiv, Kharkiv, Kryvyi Rih, Yerevan, Nizhny Novgorod, Moscow, Bishkek, Minsk hosted the football clubs Spartak. ${ }^{99}$ During 1969-1985 the same name possessed the FC "Levski" from Sofia, Bulgaria. After 1945, hockey teams Spartak were disseminated from Yugoslavia up to Bulgaria and the USSR, similarly with basketball, volleyball, rugby and handball teams. A significant number of sport complexes, stadiums gained (and sometimes still have) the name Spartak. Ultimately, one of the nicknames of the Moscow football team was the "people's team" or the "gladiators".

Spartacus was turned into a model to be followed by the Soviet youth, but the Spartakiads also "impacted society's everyday life in a way that no other political ritual, such as elections ... or May Day parades, could compare."100 Spartakiads as a phenomenon continued to remain under the total control of the USSR, especially disseminating in the countries of the socialist bloc after WWII. ${ }^{101}$ The First Polish Spartakiada was organised in 1951, the Czechoslovak one-in Prague in $1955^{102}$ Since 1958 , seven times were held the Summer Spartakiads of the Armies of the Allied States (in 1977 in Cuba) and eleven times - the Winter Spartakiads. During Khrushchev, the type of Games was reformed: since 1956 they were called the "Spartakiads of Peoples of the USSR". Until 1991, 10 summer and 7 winter Spartakiads were held and the last summer games finished in September 1991, de facto after the collapse of the USSR. ${ }^{103}$ Spartakiads became part of the sport and ideological life in Albania, Czechoslovakia and Eastern Germany. ${ }^{104}$ In Romania, they gained the name "Daciada" resembling ancient Dacia with the first competitions organized in 1977-1978. ${ }^{105}$ In 1956 a series of stamps dedicated to the Games were printed in the USSR. Explanation of the renewed interest in Spartacus and the development of the Spartakiads are explicit: it was 1955 when the Warsaw Pact was

\footnotetext{
99 Veth, "Stalinism—Football."

100 Roubal, Spartakiads, 12.

101 See "Spartakiada," Big Soviet Encyclopedia, accessed 18.03.20, https://slovar.cc/enc/ bse/2043721.html.

102 A video about the First Polish Spartakiad in 1951 is stored at "Repozytorium Cyfrowe Filmoteki Narodowej," accessed 19.03.20, http://repozytorium.fn.org.pl/?q=pl/node/ 6845; Petr Roubal, "A Didactic Project transformed into the Celebration of a Ritual: Czechoslovak Spartakiads 1955-1990," Journal of Modern European History 4, no. 1 (2006): 9o-113, https://doi.org/10.17104/1611-8944_2006_1_9o.

103 Roubal, Spartakiads, 365 .

104 Roubal, "A Didactic Project," 90, 104-105.

105 Péter László, Forbidden Football in Ceausescu’s Romania, (New York-London: Palgrave Macmillan, 2018), 25.
} 
signed, and therefore, on the international arena it was necessary to continue the socialist propaganda. Spartakiads, successfully tested in the 1920s, were quite effective by the means of demonstrating the unity of the socialist states in Central-Eastern Europe.

The masculine features of Spartacus should be also acknowledged. As emphasized earlier, the Spartakiads accompanied the socialist competition, but the heroism of the sportsmen and workers was usually focusing on male participants rather than female. ${ }^{106}$ T. Ewing argues that the power in the USSR in the 1930 " "... was emphatically masculine, in terms of both men's domination of political structures and the prevailing images of state power", crucial for the "maintenance of hierarchies". 107 Although women participated in the Spartakiads and their positions in the mass movements were strengthened during the 1930s, Spartacus's story in textbooks did not include any crucial female heroes, as his primary followers in battle were the gladiators. ${ }^{108}$ Moreover, since "sport was never separated from ideological assumptions about gender" in the Socialist countries, the Spartakiads as the festivals of sport celebrated strong physical achievements of its participants with particular accent on the men. ${ }^{109}$ Thus, Spartacus became a representation of a physically strong man after the establishment of the Spartakiads and particularly during the 193os, but his masculinity was a secondary characteristic when compared to his role in the world's revolutionary movement. ${ }^{110}$

Therefore, the usage of Spartacus's image during the Soviet period was not carried out in merely one ideological propaganda field but instead was performed in various dimensions - scientific, sport, toponymy. This allowed for the full integration and creation of the necessary propaganda image, embodied in various dimensions of everyday life.

106 Brandenberger, National Bolshevism, 29-30. For the inclusion of women in the labour and economic processes in the USSR see Wendy Z. Goldman, Women at the gates: gender and industry in Stalin's Russia (Cambridge: Cambridge University Press, 2002): 143156; Ivan Simić, "Gender Policies and Amateur Sports in Early Yugoslav Socialism," The International Journal of the History of Sport 34, no. 9 (2017): 850, http://doi.org/10.1080/o9 523367.2017 .1402762 .

107 E. Thomas Ewing, "If the Teacher were a Man': Masculinity and Power in Stalinist Schools," Gender \& History 21, no. 1 (2009): 109, 115.

108 Anna Krylova, "Stalinist Identity from the Viewpoint of Gender: Rearing a Generation of Professionally Violent Women-Fighters in 1930s Stalinist Russia," Gender \& History 16, no. 3 (2004): 627, 633 .

109 Simić, "Gender Policies," 849, 851.

110 See a study about the rise of the military narratives during the 1930s in connection to women in: Krylova, "Stalinist Identity". 
Spartacus is merely one example of the usage of antiquity for the ideological needs in the early Soviet era that has greatly influenced both historiography and the perception of particular figures and events by Soviet society. The image of Spartacus was actively exploited by the Bolsheviks since 1918, becoming particularly widespread in the 1920 s and 1930s. Stalin's speech in 1933 became a catalyst for a further historiographical boom and the development of the topic of the revolution of the slaves. Among them Spartacus was given a prominent place as a hero in the "class struggle", albeit this does not mean that Spartacus was not present in Soviet public space before. ${ }^{111}$ On the contrary, by the 1920s Spartacus was already represented as a physically strong leader and a prominent military commander of the slaves. Stalin's improvised performance defined Spartacus's fate in the Soviet socialist narrative. In the $1920 \mathrm{~s}$ his heroization had been carried out in a certain way chaotically under the influence of inertia after the revolution, often by associating the German communists with the ancient figure of Spartacus. From the 1930s, Spartacus was co-opted in the interests of the state, provoking the following historiographical discussion regarding the "revolution of the slaves".

The transformations of Spartacus's image in Soviet historiography date back to 1934-1936. Then A. Mishulin published his chief works that formed a basis of Soviet historiographical approach even though criticized by Soviet historians later. The creation of the image of Spartacus as a "people's defender" was facilitated by the repeated reprint of Raffaello Giovagnoli's novel in the USSR until the late 198 os. Similarly since the 1920s, a new type of competitionSpartakiads - was launched on the initiative of the USSR, which was an alternative to the "western bourgeois" and "capitalist and exploitative" Olympic Games. ${ }^{12}$ Spartakiads were reestablished in the USSR and expanded to the members of the socialist bloc in the 1950s.

The artificially created image of Spartacus and the usage of his name on the international sports arena is an example of the usage of ancient history for political purposes. Given the same influences of the USSR on the Central and Eastern European region, the image of Spartacus had become artificially imposed on them. Therefore, the true reception in the context of these countries is hardly worth considering: it was a constructed image that

\footnotetext{
111 Kevin M.F. Platt and David Brandenberger, Epic Revisionism: Russian History and Literature as Stalinist Propaganda (Madison, Wisconsin: The University of Wisconsin Press, 2006), 325-326.

112 Simić, “Gender Policies," 85o.
} 
has quickly disseminated in historiography and cultural life. To rephrase, the image of Spartacus was firstly shaped by the toponymy and sport and only after that started to be rethought in Soviet history-writing. The dominant reception of Spartacus's figure in the Soviet society was based not on the defined by historiography paths but rather relied on chaotic cultural (literature, cinematography), toponymic and sport practices that shaped Spartacus's figure. It can be also stated with assurance that only after publishing the Lenin's speech in 1929 and after Stalin's speech in 1933 the interests of the state were manifested explicitly within Spartacus's uprising. This proves that this is an especially interesting case in the context of other Soviet myth-making examples: history-writing was preceded by a cultural dimension which, given the relative liberalization during the New Economic Policy, could theoretically bring some unpleasant results for the Soviets. However, any cultural products that were not satisfying the Soviet leaders, like the film Spartacus (1926), were simply eliminated from memory.

\section{Acknowledgement}

This article was first presented and discussed at the workshop 'Digging Politics: The Ancient Past and Political Present in East-Central Europe' at the University College, Durham University in June, 2019 and finalized after the pleasant suggestions of the participants of the workshop and my colleagues. Especially I would like to thank Mykhailo Liakh for his suggestions, my colleagues Uliana Kashchii and William Griffiths for proofreading. See the conference report by Florian Ostrowski, "Digging Politics: The Ancient Past and Political Present in East-Central Europe," H-Soz-Kult, September 15, 2019, http://www.hsozkult.de/ conferencereport/id/tagungsberichte-8429. 